\title{
Mineral Profile of Grazing Dairy Cows Feeding in Tobaccoor Dairy Farms in the North western of Argentina
}

\author{
Gabriela Marcela Martinez ${ }^{1 *}$, Juan Francisco Micheloud ${ }^{2}$, Víctor Humberto Suarez ${ }^{2}$, Diana EstherRosa ${ }^{3}$ and \\ Guillermo AlbertoMattioli ${ }^{3}$
}

${ }^{1}$ EEA Salta - INTA, Argentina

${ }^{2}$ Área de Investigación en Salud Animal, IIACS-CIAP- EEA Salta, Argentina

${ }^{3}$ Lab. de Nutrición Mineral, F. de Ciencias Veterinarias, Argentina

Submission: March 15, 2018; Published: May 30, 2018

*Corresponding author: Gabriela Marcela Martinez, EEA Salta - INTA, Ruta Nacional 68 km, 172 (CP: 4403) Cerrillos, Salta, Argentina, Tel: 54-387-5212004; Email: martinez.gabriela@inta.gob.ar

\begin{abstract}
Dairy and tobacco productions, often complementary in the same farm, represent one of the most important economies of Salta province, Argentina. The aim of this work was to evaluate plasma levels of calcium (Ca), phosphorum (P), magnesium (Mg), copper (Cu) and zinc (Zn) between dairy cows from two tobacco-dairy farms (TDF) and from two non-tobacco dairy farms (nTDF). Blood samples were obtained of 10 cows of different physiological productive periods (pre partum, fresh cow, second third of lactation and late lactation). Values $\mathrm{Ca}, \mathrm{Mg}$, $\mathrm{Cu}$ and $\mathrm{Zn}$ serum were performed by atomic absorption spectrophotometry and P values by UV-visible spectrophotometry. The relationships between variables of serum values were analyzed using linear correlation and simple linear regression; in addition, the probability of occurrence of hypocalcemia was analyzed by odds ratio (OR). Total Ca and P levels were significantly $(\mathrm{p}<0.05)$ different between treatments (Ca: TDF $8.40 \mathrm{mg} / \mathrm{dl}$ vs nTDF 9.64 $\mathrm{mg} / \mathrm{dl}$ - P: TDF $4.74 \mathrm{mg} / \mathrm{dl}$ vs nTDF $5.69 \mathrm{mg} / \mathrm{dl}$ ) and along periods. In both groups Ca and P concentrations decreased around calving to begin to rise gradually during postpartum. In contrast, the levels of magnesemia in the present trial did not differ between systems (TDF $2.22 \mathrm{mg} / \mathrm{dl}$ vs nTDF $2.30 \mathrm{mg} / \mathrm{dl}$ ). No significant differences were observed in $\mathrm{Cu}$ and $\mathrm{Zn}$ levels between both production systems. Tobacco-dairy farms offers predisposing conditions to mineral imbalances, evidenced by a higher incidence of subclinical hypocalcemia and hypophosphatemia in dairy cows (OR hypocalcemia: 3.79, OR hypophosphatemia: 2.9).
\end{abstract}

Keywords: Metabolic diseases; Mineral imbalance; Dairy cattle; Tobacco crop; Calcium; Phosphorum; Magnesium; Copper; Fresh cow; Zinc; Hypocalcemia; Pastures; Lactation; Dairy; Agriculture; Livestock; Soil conservation; Serum

Abbreviations: N: Nitrogen; P: Phosphorus; K: Potassium; Ca: Calcium; Mg: magnesium; Cu: copper; Zn: Zinc; TDF: Tobacco Dairy Farms; nTDF: Non-Tobacco Dairy Farms

\section{Introduction}

In the last decade, an intensification process has been developed in the dairy production of north western Argentina. In Salta province, the bovine milk basin is located in Lerma Valley. Although it is a traditional tobacco area, it is common to find dairy cattle production annexed to this agricultural production. In the farms in which both activities are carried out, tobacco crop is generally the priority while milk production has the character of complementary activity [1]. However, dairy production represents one of the most important regional economies in the province. Production management practices and the genetic used (Holstein, American biotype) are similar to the rest of the principal basins of the country. Dairy production has evolved from an extensive grazing system to a more mixed system, where pastures continue to contribute about $55 \%$ of the herd's total food intake but there is growing the use of supplements in variable proportions, as the relative stocking rate increase [1$11]$.

Minerals are essential for dairy cows, and the amounts found in most feeds normally are inadequate for high milk production. If these requirements are scarce, deficiency symptoms can occur. As in other parts of the world, mineral imbalances are one of the most important problem in Salta's basin [3]. Because minerals are required for fluid balance, blood and bone development, and for maintaining a healthy nervous system, and regulating muscles, including heart muscles, is that are no doubts about the importance of minerals on the production and in dairy herd 
health [12]. Therefore, so imbalances constituting an issue of concern associated with animal welfare and the profitability of the sector [13].

Agriculture and livestock systems of the basin define crop rotations based on management practices related to soil conservation, so that after one or two periods of tobacco production, the paddocks are destined to forage production with two mainly objectives: helps in reducing soil erosion [20] and to feed dairy cattle. Although there is a lot of potential in these systems, can be exist threats that the farmers has not correctly dimensioned the risk, for example, the potential tetanizing risk when cows grass winter crops (oat or barley) after tobacco harvesting.

The mineral content of forages varies by factors such as species, phenological status, climatic and seasonal conditions, soil type and fertilization [2-10,13]. Tobacco production is characterized by high fertilization rates with nitrogen $(\mathrm{N})$, phosphorus $(\mathrm{P})$ and potassium $(\mathrm{K})$ due to the extractive nature of this crop [6-23]. This practice production leads to severe mineral imbalances in the soil [9] and in the pastures, and it is possible to increase the risk of metabolic disorders in the herd.

The aim of the present work was to evaluate the differences in the plasma levels of calcium (Ca), P, magnesium (Mg), copper $(\mathrm{Cu})$ and zinc $(\mathrm{Zn})$ between dairy cows from tobacco-dairy farms (TDF) and from non-tobacco dairy farms (nTDF).

\section{Materials and Methods}

Four dairy farms were selected, two corresponding to TDF and nTDF. The average production for herds was $7979 \pm 638$ litres of milk per lactation. Cows $(n=40)$ of two or more lactations were sampled 4 times through the year. At each time, 10 cows of different physiological productive periods were chosen at random. These periods were: pre partum (approximately 21 days before the probable calving date), early lactation or fresh cow (during the first 30 days of lactation), second third of lactation (between 90 and 120 days postpartum) and late lactation (between 200-305 days in milk). All samples corresponded to cows with 2 or more lactations.

Dairy cattle feeding were similar in the four farms sampled. During the lactation period the diet was constituted between $25-30 \%$ by pastures (fundamentally alfalfa), $30 \%$ of corn silage and $40-45 \%$ of concentrates (expeller of soya, soy bean and corn grain), while during the pre-calving period diet consisted in $50 \%$ corn silage, $30 \%$ wheat straw, $15 \%$ soybean expeller and $5 \%$ wheat bran. During all production stages and in all farms commercial mineral salts were supplied according to the manufacturer's recommendations. In addition, two of the dairy farms evaluated (one corresponding to the TDF group and the other to the nTDF group) used anionic salts during pre-calving.

\section{Biochemical analysis}

Blood samples were obtained by jugular vein puncture. Serum was extracted by centrifugation for 10 minutes at $1500 \mathrm{rpm}$. The concentrations of $\mathrm{Ca}, \mathrm{Mg}, \mathrm{Cu}$ and $\mathrm{Zn}$ were measured by flame atomic absorption spectrophotometry and $\mathrm{P}$ determinations were made by UV-visible spectrophotometry according to the manufacturer's instructions.

\section{Statistical analyses}

The relationships between variables of serum values were analyzed using linear correlation (Pearson) and simple linear regression; in addition, the probability of occurrence of hypocalcemia was analyzed by odds ratio. Differences between variables and lactation periods were examined by analysis of variance, Tukey test and Chi square using Fisher's test. Statistical differences were considered significant at $\mathrm{P}<0.05$. Statistical package InfoStat [14] was used.

\section{Reference values}

The reference values to consider clinical and subclinical hypocalcemia were $<5.5$ and from 5.5 to $<8.5 \mathrm{mg} / \mathrm{dL}$ respectively $[15,16]$. For Mg, hypomagnesemia was considered at values lower than $1.8 \mathrm{mg} / \mathrm{dL}$. For hypophosphatemia and hyperphosphatemia the reference values were $<4$ and $>6.18 \mathrm{mg} / \mathrm{dL}$ respectively [10]. $\mathrm{Cu}$ level were considered adequate when concentration was higher than $60 \mu \mathrm{g} / \mathrm{dl}$ while for $\mathrm{Zn}$ the minimum value accepted as ideal was $90 \mu \mathrm{g} / \mathrm{dl}$ [16].

\section{Results and Discussion}

\section{Macro elements: calcium, phosphorus and magnesium.}

Table 1 shows the results obtained regarding the serum calcium concentration in both treatments and throughout the entire sampling period. Concerns to the levels of calcemia, statistically significant differences were detected not only between groups but also in all the productive stages considered. The average values obtained for the TDF treatment were compatible with a subclinical hypocalcemia condition, being in turn the period of fresh cow in which the lowest concentration of calcium was detected. This decrease in Ca concentrations around calving to begin to rise gradually during postpartum was recorded in both groups, but always with lower values for the TDF.

Table 1: Mean values and standard deviation of calcemia $(\mathrm{mg} / \mathrm{dL})$ in dairy cows within TDF and $\mathrm{n}$ TDF.

\begin{tabular}{|c|c|c|c|c|c|c|c|c|c|c|}
\hline \multirow{2}{*}{ Group } & \multicolumn{2}{|c|}{ Total } & \multicolumn{2}{c|}{ Pre calving } & \multicolumn{2}{c|}{ Fresh } & \multicolumn{2}{c|}{ Second third of lactation } & \multicolumn{2}{c|}{ Late Lactation } \\
\cline { 2 - 12 } & Mean & S.D. & Mean & S.D. & Mean & S.D. & Mean & S.D. & Mean & S.D. \\
\hline TDF (n: 283) & $8.40 \mathrm{a}$ & 2.16 & $8.22 \mathrm{a}$ & 2.08 & $8.08 \mathrm{a}$ & 1.83 & $8.68 \mathrm{a}$ & 2.76 & $8.63 \mathrm{a}$ & 1.93 \\
\hline nTDF (n: 304) & $9.64 \mathrm{~b}$ & 2.27 & $9.52 \mathrm{~b}$ & 1.77 & $9.67 \mathrm{~b}$ & 2.53 & $9.79 \mathrm{~b}$ & 2.72 & $9.58 \mathrm{~b}$ & 1.91 \\
\hline
\end{tabular}

Means with a different letter within the same row are different $(P<0.05)$. 
Like in this trial, Albornoz [17] reported for dairy cows in grazing conditions a decrease in Ca levels near calving for a subsequent increase during postpartum. On the other hand, the values obtained for nTDF group were similar to those observed by Albornoz et al. [18] for dairy cattle in semi-pastoral systems $(9.32 \pm 0.08)$. The incidence of subclinical hypocalcemia was
$62.5 \%$ in the TDF and 44\% in the nTDF (Chi 60.2, p <0.0001), with a highest probability of occurrence in the first group (OR: 3,79 ). These differences were detected in all evaluated periods, and therefore they would not be due to the productive levels associated to each stage (Table 2).

Table 2: Contingency table of the number of cows with or without hypocalcemia ( $\mathrm{mg} / \mathrm{dL}$ ) by treatment.

\begin{tabular}{|c|c|c|c|}
\hline Ca & TDF & TTD & 93 \\
\hline Hypocalcemia & 177 & 211 & 270 \\
\hline Normocalcemia & 106 & 304 & 517 \\
\hline Total & 283 & 587 \\
\hline
\end{tabular}

The values of phosphorus obtained throughout all the periods are presented in Table 3. As was for the level of $\mathrm{Ca}$ in blood, $\mathrm{P}$ mean concentration throughout the entire trial was statistically different and lower in nTDF treatment. In turn, the fluctuation of $\mathrm{P}$ values in both groups was similar, resulting in a decrease in values around the birth to begin to rise later during the postpartum, Albornoz et al. [18] also reported similar behaviour for this mineral. Despite this dynamic, it should be mentioned that in both groups and throughout the sample period, the average values obtained were within the range of normality proposed by Goff [16].

Table 3: Mean values and standard deviation of phosphatemia $(\mathrm{mg} / \mathrm{dL})$ in dairy cows within TDF and $\mathrm{n}$ TDF.

\begin{tabular}{|c|c|c|c|c|c|c|c|c|c|c|}
\hline \multirow{2}{*}{ Group } & \multicolumn{2}{|c|}{ Total } & \multicolumn{2}{c|}{ Pre calving } & \multicolumn{2}{c|}{ Fresh } & \multicolumn{2}{c|}{ Second third of lactation } & \multicolumn{2}{c|}{ Late lactation } \\
\cline { 2 - 12 } & Mean & S.D. & Mean & S.D. & Mean & S.D. & Mean & S.D. & Mean & S.D. \\
\hline TDF (n: 283) & $4.74 \mathrm{a}$ & 1.24 & $5.05 \mathrm{a}$ & 1.25 & $4.51 \mathrm{a}$ & 1.26 & $4.69 \mathrm{a}$ & 1.49 & $4.72 \mathrm{a}$ & 0.97 \\
\hline $\mathrm{nTDF}(\mathrm{n}: 304)$ & $5.69 \mathrm{~b}$ & 1.50 & $6.06 \mathrm{~b}$ & 1.65 & $5.29 \mathrm{~b}$ & 1.14 & $5.71 \mathrm{~b}$ & 1.51 & $5.73 \mathrm{~b}$ & 1.62 \\
\hline
\end{tabular}

Means with a different letter within the same row are different $(P<0.05)$.

However, if the individual values are considered in both treatments there are animals with serum levels of $\mathrm{P}$ below the normal limits (Table $4 \& 5$ ). The phosphatemia registered two types of imbalances: around $17 \%$ of the animals presented hypophosphatemia, while $23.2 \%$ hyperphosphatemia. In turn there were differences between the groups, a higher proportion of hypophosphatemic cows in the TDF (27\%) than in the nTDF (11\%) (Chi 17.01, p <0.0001) were detected. The
OR value obtained indicates that cows from TDF are 2.90 times more likely to have hypophosphatemia. These differences were repeated in all periods evaluated. Conversely, when evaluating the proportion of hyperphosphatemic cows the largest number of animals in this condition was identified in the nTDF (32\%) while in the TDF it was $10.8 \%$ (Chi 23.7, p <0.0001). Thus, the OR indicates that cows from the nTDF are 3.84 times more likely to suffer hyperphosphatemia (Table 5).

Table 4: Contingency table of the number of cows with or without hypophosphatemia ( $\mathrm{mg} / \mathrm{dL})$ by treatment.

\begin{tabular}{|c|c|c|c|}
\hline $\boldsymbol{P}$ & TDF & nTDF & Total \\
\hline Hypophosphatemia & 42 & 30 & 72 \\
\hline Normopophosphatemia & 114 & 236 & 350 \\
\hline Total & 156 & 266 & 422 \\
\hline
\end{tabular}

Table 5: Contingency table of the number of cows with or without hyperphosphatemia $(\mathrm{mg} / \mathrm{dL})$ by treatment.

\begin{tabular}{|c|c|c|c|}
\hline $\boldsymbol{P}$ & TDF & nTDF & Total \\
\hline Hyperphosphatemia & 17 & 85 & 102 \\
\hline Normopophosphatemia & 139 & 181 & 320 \\
\hline Total & 156 & 266 & 422 \\
\hline
\end{tabular}

Horst \& Goff $[19,20]$ indicate that phosphatemia is influenced by the physiological state of the animals and the amount of milk produced, although the content of the mineral in the food is one of the most relevant factors in the determination of the level of serum phosphorus. So that, it can be suggested that the diets in the TDF are more deficient in P than those from nTDF. This excess of P observed in the nTDF would lead to greater excretion of it in the faeces and consequently to the soil and forages.

The average values of magnesium concentration in blood throughout the entire trial period and for both treatments are presented in Table 6. 
Table 6: Mean values and standard deviation of magnesemia $(\mathrm{mg} / \mathrm{dL})$ in dairy cows within TDF and $\mathrm{n}$ TDF.

\begin{tabular}{|c|c|c|c|c|c|c|c|c|c|c|}
\hline \multirow{2}{*}{ Group } & \multicolumn{2}{|c|}{ Total } & \multicolumn{2}{c|}{ Pre calving } & \multicolumn{2}{c|}{ Fresh } & \multicolumn{2}{c|}{ Second third of lactation } & \multicolumn{2}{c|}{ Late lactation } \\
\cline { 2 - 12 } & Mean & S.D. & Mean & S.D. & Mean & S.D. & Mean & S.D. & Mean & S.D. \\
\hline TDF (n: 283) & $2.22 \mathrm{a}$ & 0.38 & $2.16 \mathrm{a}$ & 0.37 & $2.28 \mathrm{a}$ & 0.44 & $2.22 \mathrm{a}$ & 0.32 & $2.22 \mathrm{a}$ & 0.37 \\
\hline $\mathrm{nTDF}(\mathrm{n}: 304)$ & $2.30 \mathrm{a}$ & 0.47 & $2.19 \mathrm{a}$ & 0.42 & $2.32 \mathrm{a}$ & 0.51 & $2.35 \mathrm{a}$ & 0.46 & $2.31 \mathrm{a}$ & 0.44 \\
\hline
\end{tabular}

At no time and in any of the treatments there were significant differences regarding the blood magnesium content. In turn, even when average magnesemia values remained within the range of normality proposed by Kaneko et al. [21] (1.7 to $3.0 \mathrm{mg} / \mathrm{dL}$ ), they were significantly lower during pre-calving (Table 6). Values similar to those obtained in the present trial were reported by Albornoz et al. [18] for animals under semi-pastoral systems.
Despite the fact that the average values were found within what was considered adequate, $17.8 \%$ of the animals sampled showed hypomagnesemia (105/587) (Table 7). Similar results have been registered by Suarez \& Martínez [1] who reported values of up to $46 \%$ of subclinical hypomagnesemia in dairy herds of Salta's basin.

Table 7: Contingency table of the number of cows with or without hypomagnesemia ( $\mathrm{mg} / \mathrm{dL})$ by treatment.

\begin{tabular}{|c|c|c|c|}
\hline $\boldsymbol{P}$ & TDF & nTDF & Total \\
\hline Hypomagnesemia & 54 & 51 & 105 \\
\hline Normomagnesemia & 229 & 253 & 482 \\
\hline Total & 283 & 304 & 587 \\
\hline
\end{tabular}

Goff [22] mentions that, although hypomagnesemia in dairy herds can be sporadic and of variable incidence, it is possible that it affects up to $20 \%$ of grazing cows, a percentage similar to that obtained in the present trial. Recent studies indicate that hypomagnesemia affects calcium homeostasis, increasing the risk of hypocalcemia. This is because low magnesemia reduce the response of tissues to PTH and active vitamin D. In contrast with $\mathrm{Ca}$ and $\mathrm{P}$ concentrations, the levels of hypomagnesemia in the present trial did not differ between systems (TDF: 19\% vs nTDF: $16.7 \%$, Chi $0.53, \mathrm{p}<0.47$ ), even when production stages were considered (Table 6). Hypomagnesemia usually occurs at the beginning of lactation, although it can also occur at the end of pregnancy, in animals that graze fast-growing forages with high concentrations of potassium and nitrogen and low levels of $\mathrm{Mg}$ and sodium [23].

\section{Micro elements: Copper and Zinc.}

At evaluate serum $\mathrm{Cu}$ levels between TDF and nTDF, no significant differences were found between sampling periods ( $p<0.2801$ ), whereas significant differences ( $p<0.0002)$ were observed when average value was considerate. In spite of this, the average values of cupremia were within the established reference limits (TDF: $74.7 \pm 16 \mu \mathrm{g} / \mathrm{dl}$, nTDF: $79.8 \pm 40 \mu \mathrm{g} / \mathrm{dl}$ ). Similarly, Zn serum concentration was found between the limits established as normal (TDF: $110 \pm 34 \mu \mathrm{g} / \mathrm{dl}$, nTDF: $109 \pm 31 \mu \mathrm{g} /$ dl). No significant differences were observed between treatments ( $p<0.5658)$ or production stages $(\mathrm{p}<0.0246)$.

At comparing the proportion of animals that were below the reference values in $\mathrm{Cu}(\mathrm{p}<0.28)$ and $\mathrm{Zn}(\mathrm{p}<0.89)$, no significant differences were observed between TDF and nTDF. Only just near $10 \%$ of the animals were below the normal limit $(\mathrm{Cu}: 10.3 \%, \mathrm{Zn}$ :
7.5\%). This result is encouraging, since $\mathrm{Cu}$ and $\mathrm{Zn}$ are essential microelements for antioxidant function, and play a fundamental role in the immune system in dairy cows.

\section{Conclusion}

This research demonstrates that tobacco-dairy farms offers predisposing conditions to mineral imbalances, evidenced by a higher incidence of hypocalcemia and hypophosphatemia in dairy cows (OR hypocalcemia: 3.79, OR hypophosphatemia: 2.9). However, non-tobacco dairy farms offer a higher proportion of hyperphosphatemic cows (OR: 3.84). Interestingly, no significant differences were observed in the $\mathrm{Cu}$ and $\mathrm{Zn}$ levels between both production systems [24-27].

Based on the results obtained it is suggested continue to deepen on the particular features of dairy production associated with tobacco crop and the possible consequences on the mineral imbalances in dairy cattle.

\section{Conflict of Interest}

The authors declare that they have no conflict of interests on the writing and publishing of this manuscript.

\section{References}

1. Suarez VH, Martínez GM (2015) Características y Problemáticas Productivas - Sanitarias de la Lechería del Valle de Lerma (Salta). INTA p. 76.

2. Martínez GM, Suarez V (2015) Caracterización de los sistemas productivos de leche del Valle de Lerma, Salta. Revista Argentina de Producción Animal 35(1): 83-136.

3. Martínez GM, Micheloud JF, Suarez VH, Yanitto N (2016) Efecto del incremento en la concentración de magnesio dietario preparto sobre el pH urinario en vacas lecheras. Revista Argentina de Producción Animal 36(1): 63:70. 
4. MCdowell LR (2002) Recent advances in mineral and vitamins on nutrition of lactating cows. Pakistan Journal of Nutrition 1(1): 8-19.

5. Reinhardt TA, Horst RL, Goff JP (1988) Calcium, phosphorus, and magnesium homeostasis in ruminants. Vet Clin North Am. Food Anim Pract. 4(2): 331-350.

6. Rodriguez Faraldo M, Zilocch H (2012) Historia del cultivo de tabaco en Salta.

7. Satter LD, Klopfenstein TJ, Erickson GE (2002) The role of nutrition in reducing nutrient output from ruminants. J AnimSci 80: 143-156.

8. Sepulveda P, Wittwer F, Bohmwald, H, Noro M (2011) Relacion entre la hiperfosfatemia y la hipocalcemia subclinica en vacas lecheras. Rev Arg Prod Anim p. 31,39.

9. Sifola, MI, Postiglione L (2003) The effect of nitrogen fertilization on nitrogen use efficiently of irrigated and non-irrigated tobacco (Nicotianatabacum L). Plant and Soil 252: 313-323.

10. Soder KJ, Stout WL (2003) Effect of soil type and fertilization level on mineral concentration of pasture: potential relationships to ruminant performance and health. J Anim Sci 81: 1603-1610.

11. Spears JW, Weiss WP (2008) Role of antioxidants and trace elements in health and immunity of transition dairy cows. The Vet J 176(1): 70-76.

12. Goff JP (2004) Macromineral disorders of the transition cow. Vet Clin North Am Food Anim Pract 20(3): 471-494.

13. Khan ZI, Hussain A, Ashraf M, Ashraf MY, Yousaf M et al. (2004) A review on mineral imbalances in grazing livestock and usefulness of soil, dietary components, animal tissues and fluid analysis in the assessment of these imbalances. J Anim Vet Adv 3: 394-412.

14. Di Rienzo JA, Casanoves F, Balzarini MG, Gonzalez L, Tablada M et al (2008) InfoStat, versión, Grupo InfoStat, FCA, Universidad Nacional de Córdoba, Argentina.

15. Chapinal N, Leblanc S, Carson M, Leslie K, Godden S et al. (2012) Herd-level association of serum metabolites in the transition period with disease, milk production, and early lactation reproductive performance. J Dairy Sci 95(10): 5676-5682.
16. Goff JP (2006) Macro mineral physiology and application to the feeding of the dairy cow for prevention of milk fever and other peri parturient mineral disorders. Animal Feed Science and Technology 126(3,4): 237 257.

17. Albornoz L, Albornoz JP, Cruz JC, Fidalgo LE, Espino L et al. (2017) Estudio comparativo de los niveles de Calcio, Fosforo y Magnesio durante el periparto en vacas lecheras en diferentes sistemas de producción en Uruguay y España. Veterinaria (Montevideo) 53(205): 4-12.

18. Albornoz L (2006) Hipocalcemia puerperal, variaciones de minerales en el periparto y evaluación de tratamientos. Tesis de Maestría, Programa de Posgrados de la Facultad de Veterinaria, UdelaR, Montevideo, Uruguay.

19. Horst RL (1986) Regulation of calcium and phosphorus homeostasis in the dairy cow. J Dairy science, 69(2): 604-616.

20. Goff JP (2000) Pathopysiology of calcium and phosphorus disorders. Vet. Clin. North Am. Food Anim Pract 13: 619-639.

21. Kaneko JJ (2008) Clinical Biochemistry of Domestic Animals. ( $6^{\text {th }}$ edn), San Diego, USA Academic Press, USA pp. 904.

22. Goff JP (2014) Calcium and magnesium disorders. Veterinary Clinics of North America: Food Anim Practice 30(2): 359-381.

23. Goff JP (1998) Ruminant hypomagnesemictetanies. Current Veterinary Therap: Food Animal Practice. ( $4^{\text {th }}$ edn), Edited by Jimmy L. Howard. W.B. Saunders. Philadelphia, USA. p. 1-9.

24. Ballari MH (2005) Tabaco Virginia: Aspectos ecofisiológicos de la nutrición en condiciones de cultivo. Ed Alejandro Graziani S.A. Córdoba. Argentina. pp. 223.

25. Fernández de Ullivarri D (1990) Manual 1: El cultivo de los tabacos claros. EEA INTA Cerrillos. Salta. p. 78.

26. Suttle NF (2010) Mineral Nutrition of Livestock. The Mineral Nutrition of Livestock. 4th ed. CABI Publishing, Wallingford, UK.

27. Goff JP (2008) The monitoring, prevention, and treatment of milk fever and subclinical hypocalcemia in dairy cows. Vet J 176(1): 50-57.

\section{Your next submission with Juniper Publishers} will reach you the below assets

- Quality Editorial service

- Swift Peer Review

- Reprints availability

- E-prints Service

- Manuscript Podcast for convenient understanding

- Global attainment for your research

- Manuscript accessibility in different formats

( Pdf, E-pub, Full Text, Audio)

- Unceasing customer service

Track the below URL for one-step submission

https://juniperpublishers.com/online-submission.php 